\title{
Actual Costs of Uneconomic Growth of Marine Fisheries in China's Pearl River Delta
}

\author{
Ying Wang \\ Zhejiang Provincial Key Research Institute of Philosophy and Social Sciences for Ecological Civilization School of Economics and \\ Management, Zhejiang Sci-Tech University, Hangzhou, China \\ Email: es03ying@163.com
}

How to cite this paper: Wang, Y. (2018) Actual Costs of Uneconomic Growth of Marine Fisheries in China's Pearl River Delta. Natural Resources, 9, 297-312. https://doi.org/10.4236/nr.2018.97018

Received: June 27, 2018

Accepted: July 22, 2018

Published: July 25, 2018

Copyright (c) 2018 by author and Scientific Research Publishing Inc. This work is licensed under the Creative Commons Attribution International License (CC BY 4.0).

http://creativecommons.org/licenses/by/4.0/

\begin{abstract}
As traditional economic theory is mainly based on neoliberal principles, whose failure is to ignore the ecological component in value assessment methods, it assumes that continuous economic growth exists with high level of employment and low inflation rate. Many ecological economists have criticized the blind pursuit of short-term economic interests in the last 30 years for leading to loss of natural capital and ecosystem services. This study demonstrates the concept of "uneconomic growth" by measuring the actual costs of fishing activities and fishery policy implemented in China's Pearl River Estuary from economic, social, and ecological aspects. The results show that the costs of economic growth exceed the benefits of additional growth because of the limits of the ecosystem. The ecological system of the Pearl River Estuary has been degraded significantly by overfishing and is regarded to be under non-optimal conditions regarding both ecological and socio-economic objectives.
\end{abstract}

\section{Keywords}

Actual Costs, Uneconomic Growth, Ecological-Economic-Social Aspects, Pearl River Estuary

\section{Introduction}

Fisheries are considered as critical sources of food, income, and jobs for coastal people. Meanwhile fisheries are renewable common resources exploited by surrounding fishing communities that benefit from the economic rent of natural resources [1]. However, conflicts are arising from excessive fishing effort and increasing economic and social pressure [2]. Ecological economists [3] [4] have criticized that the blind pursuit of short-term economic interests of fisheries has 
had deleterious effects on fish stock, ecosystem construction, and economic revenue of fisheries. Daly and Farley [5] put forward the concept of "uneconomic growth", defined as the marginal cost of economic growth exceeds the marginal benefits. Furthermore, the concept of "unjust uneconomic growth" has been proposed to reveal that uneconomic growth is also the causes of social tensions and conflicts, as both the benefits and costs of economic growth are distributed unjustly [6]. Marine economists and ecologists have begun to recognize the assessment of fishing activities and public policy should consider not only economic and social benefits but also the need to take into account ecological and social costs [7].

In the last 30 years, many works in the literature have been developed, and they have challenged the theory of unlimited economic growth and brought about a new field of study in ecological economics. Some concepts are emerging, such as degrowth [8] [9] [10] and a-growth [11]. According, "degrowth" suggests a downscaling of the economy so as to make it stay within planetary boundaries [12]; "a-growth" proposes to focus on economic, social, and environmental policies are independent of their impact on economic growth but ignore GDP information [13]. The concept of "uneconomic growth" belongs to this increasing number of research. This concept was defined within the schema theory that the economic system is a subsystem of the ecosystem, which limits the possibility of unlimited growth [5]. From the uneconomic growth perspective, the current social-ecological-economic crisis is the result of systemic limits to growth and the obsession with growth at all costs. If taking the social aspect into account, uneconomic growth is not only environmentally unsustainable, but also socially unjust. In addition, the population explosion and economic growth lead to uneven distribution of wealth and power, which can be the cause of many social contradictions and conflicts. When the social costs of dealing with rising unfairness in social-wealth distribution are higher than the economic benefits of increased economic growth lead to more serious social contradictions, it becomes unjust uneconomic growth. This serious wealth inequality is related to a series of social problems, such as increased physical and mental diseases, lower life expectancy, poorer educational performance and higher crime rate [14]. However, majority of the academic uneconomic growth discourse originate from Europe, few of the articles were written by emerging or low-income countries [10]. Additionally, empirical analyses of the uneconomic growth are still scarce. The topic of resource overexploited mainly focus on energy [15] and mineral resources reserves [16], which should be expanded to other renewable resources.

Fisheries are typical renewable common resources and exploited by adjacent fishermen based on complex socioeconomic and ecological systems. Owing to the biomass dynamics of the fishery resource, the availability of renewable resources fluctuates frequently [6]. In fact, the characteristics of fisheries, especially small-scale fisheries, are usually defined as poor, marginalized, vulnerability, exclusion, exploitation and discrimination, these processes in this particular fishery environment show different forms and combinations [17] [18] [19]. The 
debate about fishermen's poverty has widely regarded as "fisheries rhymes with poverty" and the roots of the problem stems from the economic and biological characteristics of the fishing activity. Because overcapacity is one of the leading causes of overfishing in most near-shore fishing, the poverty of fisheries can be expressed as the linear relationship between the low income of fishermen and the overexploitation of fishery resources. Consequently, these coastal people are experiencing decreasing economic efficiency and increasing conflict, affecting both environmental sustainability and social security. These conditions lead to unsustainable economic growth and raise the discussion of a solution of welfare maximization for fishing communities.

Nowadays, it is widely considered that most fisheries in the coastal region of southeast Asia have been experiencing biological decline due to growing fishing pressure [20]. In this study, the theory of uneconomic growth will be applied to analyze the actual cost of fishing activities in the Pearl River Delta (PRD) of China. The PRD is a typical subtropical marine ecosystem surrounding the mouth of the Pearl River in Guangdong Province, where the Pearl River flows into the South China Sea (Figure 1). In addition, the Pearl River Estuary (PRE) is one of the most important fishing grounds in the South China Sea. The inflows of both seawater and fresh water makes it possible to provide abundant nutrients in both the water and sediment, which makes the estuary become one of highest productive natural habitats in the world [21]. The nutrient-rich water resources support the biodiversity and productivity while maintaining the important commercial exploited fisheries. Due to the special hydrological characteristics of estuary, the Pearl River involving a large variety of species [22] [23]. However, the rapid increase of population density in the Pearl River Delta has led to an increase in food demand and severe pressure on fishery resources [24]. Consequently, the delta region is now facing increased dissipation of economic rent and social instability, affecting both sustainable use of resources and social security, which is a typical example of uneconomic growth. This study aims to demonstrate the concept of "uneconomic growth" by measuring the actual costs of fishing activities and fisheries policy implemented in the PRD of China from economic, social, and ecological aspects.

\section{Ecological Dimension}

\subsection{The Ecological Impacts of Fishing}

At the end of 1978, fishing fleets began to privatize in the Pearl River Delta since the beginning of economic reform of China, which has led to a significant increase in fishery investment and number of fishing boats as well as improvement in fishing technology [25]. Consequently, there has been a substantial growth in catches of various fishing gear in the PRD since 1979, which peaks in 1998 was five times as much as that in 1979 (Figure 2). To address the problem of overfishing, China proposed a zero-growth policy for fresh and marine fishing in 1999. Although the aim of Chinese fishery administration departments is to 




Figure 1. Map of the Pearl River Estuary coastal ecosystem.

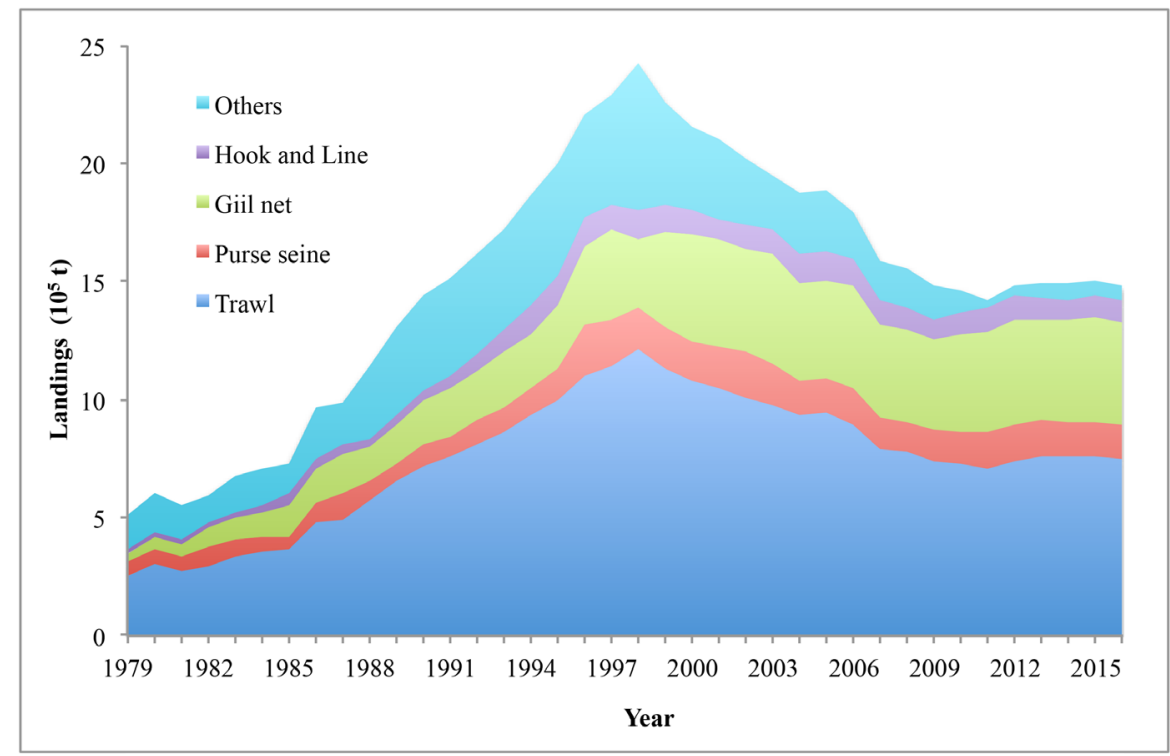

Figure 2. Total landings in the Pearl River coastal by gears from 1979 to 2016.

promote the relocation of fishermen, reduce the fishing input and control the number of fishing boats and its total engine power over the past decade, the pol- 
icies implemented to address the ecological and social crises have not solved the problems effectively [26].

Figure 3 indicates that the number of vessels and power still increased by 4.6 and 3.5 times in the PRD from 1979 to 2016 and the trawlers were the largest catches in all kinds of fishing gear (Figure 2). The index of catch per unit effort (CPUE), which is measured by the ratio of total catches to engine power, shows a decreasing trend from 1998 to 2016 (Figure 4). It indicates the numbers of fishing vessels and thus, their fishing effort have far exceeded the carrying capacity of the fishing ground. Nevertheless, fishing activities have led to natural resource and economic efficiency losses, whose consequence are still present today. To control fishing effort, the number of vessels and engine power should be reduced.

Additionally, demersal species are exploited more serious than pelagic species in the PRD ecosystem. As previous studies suggested that this over-fishing is brought about by intensive bottom trawling operations, which are the root cause of the current difficult fisheries situation [27]. Although the demersal fishes have severely damaged by the trawlers, the loss of demersal species have been economically compensated by substantial increase in landings of shrimp and shellfish [24]. Likewise, purse seining captures most of the juveniles, which also strongly contribute to most depleted species that are fully overexploited.

According to our previous study [21] [24] [28], with the increasing impact of human activities on estuarine ecosystems and insufficient protective policy, the stocks of commercial exploited species in the PRD decreased dramatically since 1970s. Hairtail, blue scad and pomfret are three main commercial exploited marine species that favored by local residents. Although the hairtail and blue scad still have a high catch rate, they are also under the threat from overfishing that smaller-size and lower value. Other major economically fishes such as golden threadfin bream, Japanese scad, jack mackerel, masked spinefoot, silver croaker, greater lizardfish, bensasi goatfish, melon seed, and lesser-spotted leatherjacket, have shown similar trends that "fishing down the food web" in their ecological functional structure [29]. These trends were first demonstrated by the fisheries scientist Daniel Pauly," the large predatory fish on top of the food web having depleted, turn to increasingly smaller species, finally ending up with small fish and invertebrates" [30]. It seems that since 1979, the PRD ecosystem has changed dramatically from large-size and high-value demersal fish-based ecosystem to small-size and low-value pelagic fish-based ecosystem [21] [25].

\subsection{The Society Economic Welfare of Fishing Communities}

Neoclassical economics provides a theoretical framework in the form of neoliberalism, which promises to deliver widespread prosperity supported by continuous economic growth, defined as an increase in gross domestic product (GDP) [31] [32]. The main tool for their distribution through public policy decisions is the value-neutral framework of cost-benefit analysis [6]. The indexes of 


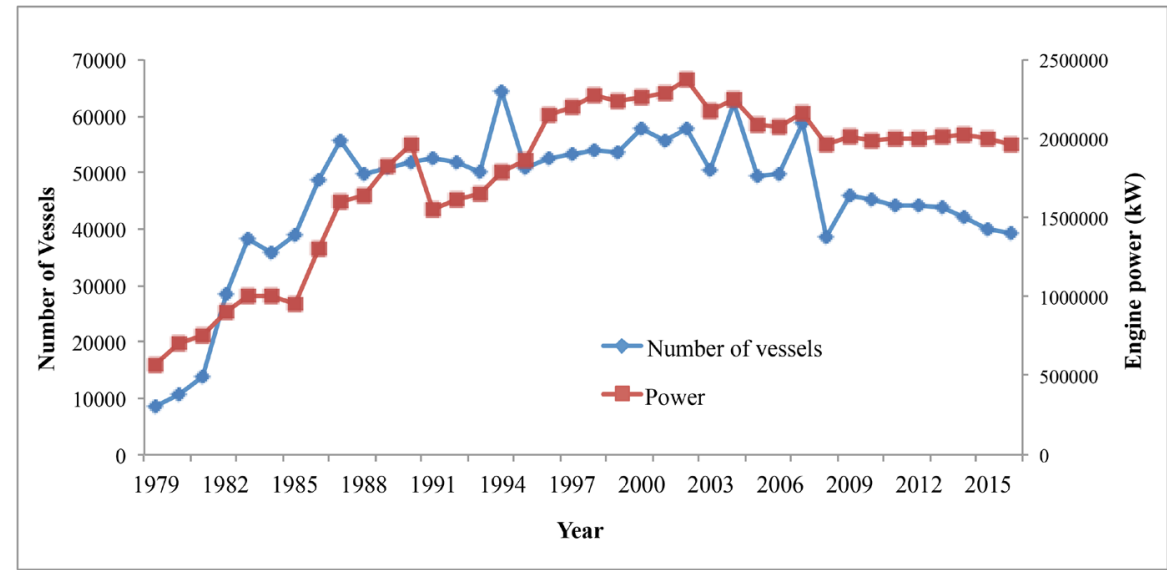

Figure 3. Numbers of fishing boats and engine power in the PRD from 1979 to 2016.

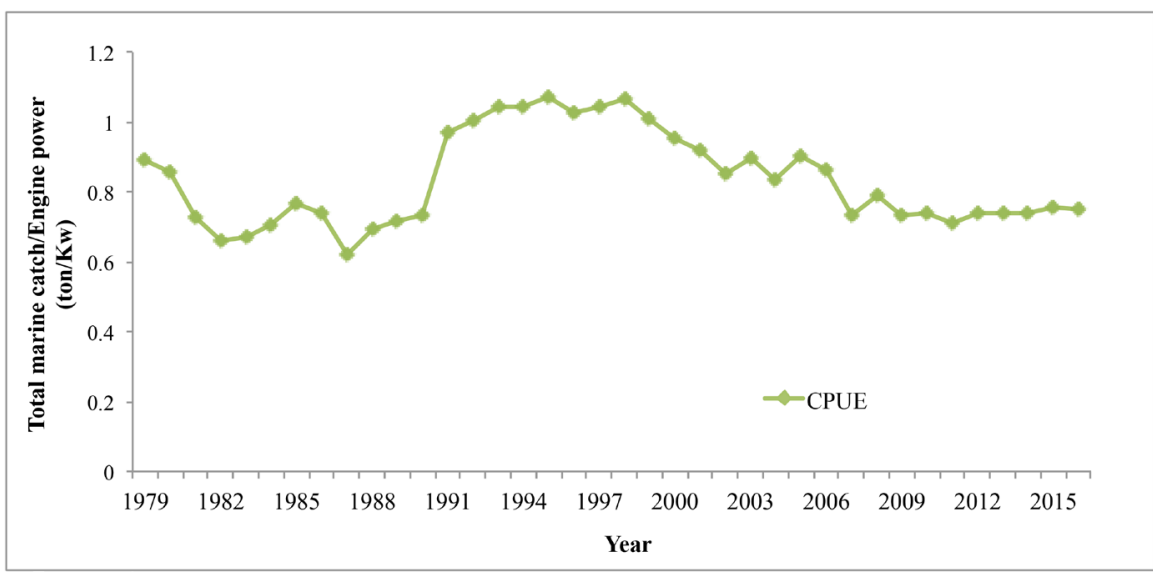

Figure 4. Ratio of total marine catch to engine power in 1979 to 2016.

value add of marine capture (GDP), which is equal to national income, are applied to reflect the economic revenue. The GDP of marine capture in the PRD experienced a decline in 2010 and 2011, and then showed a steady growth from 2012 to 2015 (Figure 5). The total output value of marine capture reached 2.124 billion dollars in 2016 (Yuan are converted into dollars based on an average exchange rate in the current year, similarly hereinafter), representing $11.53 \%$ of the output of the PRD's fishing sector (18.419 billion dollars) at current prices, with total employment of 257,458 wild capture harvesters scattered throughout 1013 communities. This figure translates to more than 514,916 individuals who rely on the marine capture fishing industry as their primary source of livelihood, using a dependency ratio (household members/labour) of fisher households of 2.06 in 2016.

Social factors often include the well-being of fishermen's communities and the livelihoods of fishermen [33]. Income distribution of residents is often considered as one of the key determinants of the social benefits and costs of fishing activities, which is closely linked to welfare, education, health and other income-related social issues. It is believed that economic growth would reduce 


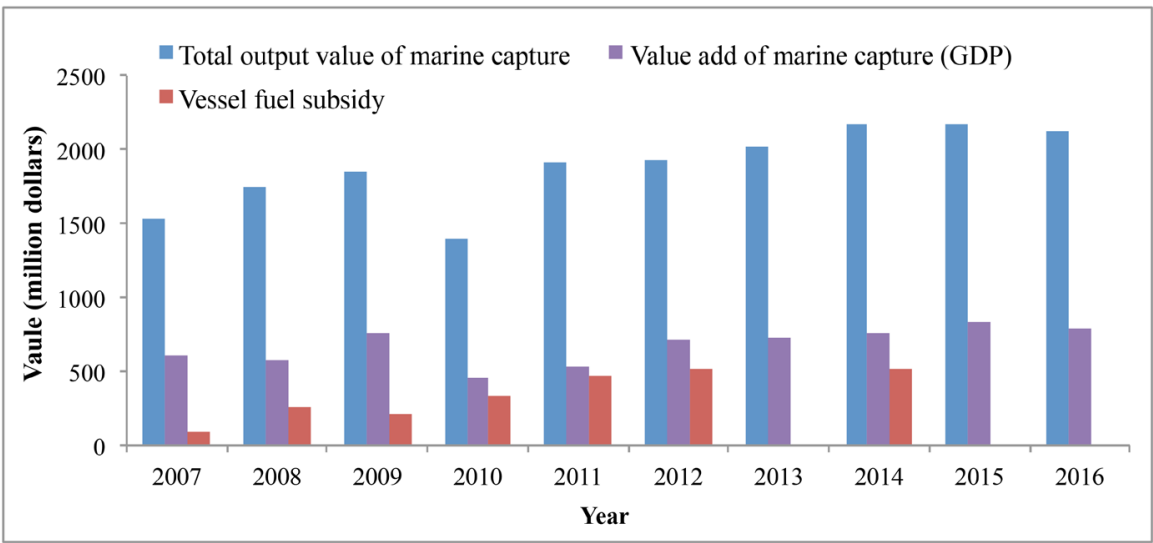

Figure 5. Total output values of marine capture, value add of marine capture and vessel fuel subsidy in 2007-2016.

poverty, but it has turned out that when wealth increase leads to more serious income inequality, the costs of addressing rising social contradictions are higher than the benefits of the increased economic outputs. To address social cost, at first, this study defines a society's economic position that an ideal level of personal income in a society is known. If real income is defined as social benefit, the difference between the ideal and real situation provides the measure of social cost. Since it is difficult to define the value of ideal levels, it is assumed the local residents' average income level is an ideal level for fishers. Thus, the social cost is the difference between local residents' average income and those of fisher households in the PRD. The annual per capita net income of urban, rural, and fishing households is shown in Figure 6. As can be observed from the chart, the annual per capita net income of urban, rural, and fishing households increased from 1979 to 2016. However, the ratio of per capital annual net income between urban and fishing households is increasing but the ratio of per capital annual net income between fishing and rural households is decreasing (Figure 7), which reveals that the income gap between urban and fishing households is enlarging, while the income gap between fishing and rural households is narrowing. This indicates that the advantages of marine fisheries capture compared with agriculture are declining and less economic benefits are gained from fishing activities as fishing stocks have become depleted in the PRD.

\subsection{Fishing Policy Implementation in the PRD}

Before the year of 1980, the development of China's fishing industry mainly depended on quantity. From the 1990s, growth of fisheries in China began to shift from "extensive" to "intensive", it pays more attention to quality and ecological benefits [26]. Since then, the fishery administration has issued a series of policies to improve the management of marine fishery resources, including fishing license systems, minimum mesh size regulations, summer fishing moratoria, fishing catch restrictions, and other fisheries control programs [27]. Although a series of action has been implemented to promote recovery of marine ecosystem, 


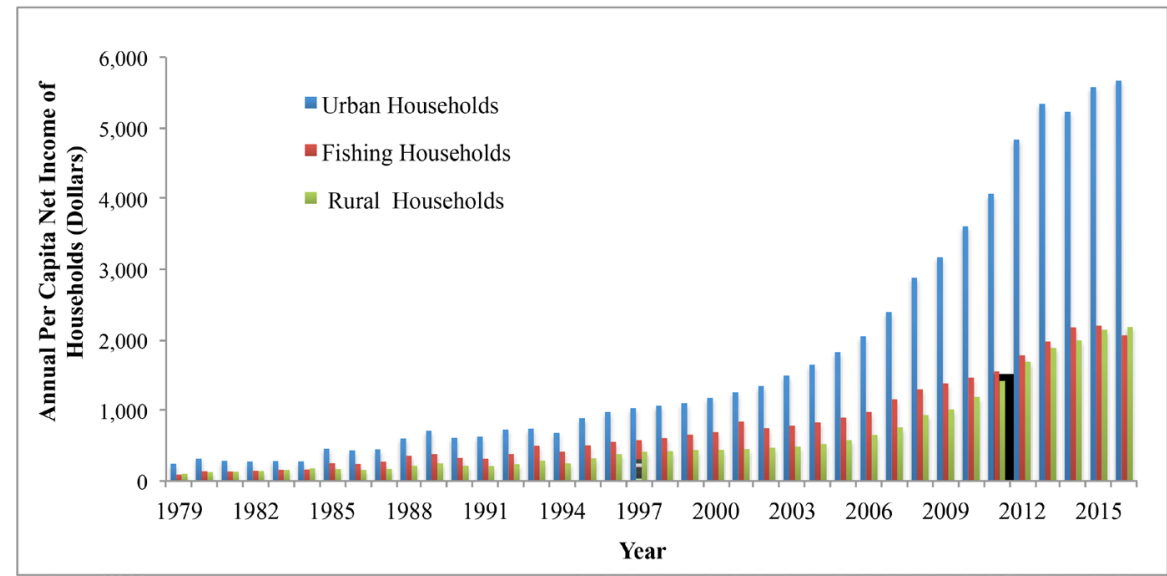

Figure 6. Annual per capita net income of urban, fishing, and rural households in 1979-2016.



Figure 7. Ratio of annual per capita net income of three categories of households in 1979-2016.

the depletion of fishery resources in coastal waters of China is an indisputable fact [26].

There are still many problems in the process policy implementation. At present, the relevant laws and regulations system is imperfect, fisheries law enforcement officer and equipment for fisheries management is not insufficient. For example, the fishing moratorium system can protect young fish and eggs during the closure time and area, however, overfishing is still there because of increased fisheries technologies and tools [29]. Although the time dimension of fishing has been effectively suppressed, the reduction of fishing effort is difficult to monitor. The achievements of the moratorium will disappear in two or three months after the moratorium because nearly all the vessels rush into the ocean [34].

Beyond that, China is also considered to be the world's second largest fisheries subsidizer [35]. Previous research showed that about $95 \%$ of fisheries subsides were harmful to fishery resource recovery in China [36]. In the PRD (Figure 1), vessel fuel subsidies started in 2007 under a protection program of agricultural 
input support (e.g. Fertilizer, fuel, seeds, and machinery) offered directly by central authorities and complemented by local governments. The fisheries subsidies reached 97.345, 254.808, 219.550, 340.212, 477.082, 512.690 and 520.935 million dollars in each of the years from 2007 to 2012 and 2014, respectively (Figure 3). In addition, fisheries diesel subsidies became the highest subsidies in a series of subsidy policies. According to the investigation results, $94 \%$ of fisheries subsidies were in the form of fuel subsidies in China [36], and it had been estimated that direct fuel subsidies account for $67.79 \%$ of the total subsidy for fishing activities and up to $35.6 \%$ of operating costs in Guangdong province [37]. To relieve the pressure of overcapacity, Guangdong province put forward a program of "fishing and aquaculture oil price subsidy adjustment implementation plan (2015-2019)" that funded at 2.36 billion dollars (using the average 2015 exchange rate, $\$ 1=¥ 6.23)$. The program aims at delicensing and scraping a total of 4782 fishing vessels from 2015 to 2019. In terms of engine power, the objective of program is reducing 245,250 kw from 2015 to 2019. The domestic fishery industry in the PRD of Guangdong province in 2019 to subsidies for oil prices should reduce to the level of subsidies in 2014.

\subsection{The Actual Costs of the PRD' Fishery}

The PRD is considered an economically developed area of China, where in the past, capture of marine stocks dominated fishery production statistics. However, overfishing has resulted in significant changes in fisheries resources, ecosystem structure and fishery economy of the PRD.

The focus of fisheries policy formulation is sustainable growth of the fishery economy, so at least three very important actual costs of fishing activities need to be considered. One is ecological cost, refers to the ecological pressure on commercially exploited species, such as Cephalopods, horse mackerel, Janpanesescad, Trichiurus hairtail, melon seed, threadfin bream, and bigeyes, etc. Commercial fisheries are intensively harvested in the PRE and most are sold as fresh fish instead of processed fish. There is a long history of eating fresh fish in the $\mathrm{PRD}$, and local residents prefer fresh fish, especially wild fish. In particular, there is cultural resistance that local residents believe that farmed fish are not nutritious enough. Of course, there are even more objective reasons for this resistance: the taste of most farmed fish may not be delicious as wild fish and excessive medication caused by excessively high fish density in the fish farming industry [26] [38]. Although aquaculture fisheries could partly alleviate the pressure on wild fish resources the bias against farmed fish make it become a major challenge [39]. As a consequence, because of people's preference for wild fish, fishers are still keen on fishing as they obtain higher prices for wild fish. Thus, the pressure on wild fish resources still continues, despite the continual decline of fisheries resources and the increasing cost of fishing. This is a critical factor why it is difficult to reduce fishing efforts in most of coastal in China [27].

The second cost is social cost. The difference of annual per capital net income between urban and fishing households is increasing in the PRD region. The de- 
clining economic efficiency of fisheries leads to higher social inequality, which is associated with more health and social problems, including poorer health status, lower educational performance, and heightened violence. However, another important social cost is the loss of young fishermen, who represent the future development of the fishery economics. Nowadays, the fishing harvest sectors are characterized by population ageing that is trapped in a lack of highly professional and dedicated fishermen.

The third cost is the cost of policy. About 95 per cent of China's fisheries subsidies are detrimental to sustainable development, with almost 94 per cent of them in the form of fuel subsidies. The poor financial performance of the harvesting sector can explain the high dependence of fishermen on government fishing subsidies. This monetary cost is a burden on the government, and their fiscal spending may have better uses, such as restructuring the fishing industry.

The fishing cost of uneconomic growth can be classified as quantifiable and unquantifiable. The quantifiable monetary costs can be calculated conveniently using statistical methods. The non-quantifiable costs are represented by ecological and social loses, which excludes the value of goods and activities outside of market prices. As the contradictions between the socioeconomic development and nature resource exploitation become increasingly prominent, it is necessary to establish a comprehensive value appraisal framework to assess the total benefit and cost of fishing activities and policy decisions.

\section{Discussion}

\subsection{The Theory of Uneconomic Growth}

The theoretical background of economics shows that the principle of economics is mainly based on neoliberalism, which have some methodological defects that are mainly due to the lack of an appropriate theory of value assessment. Therefore, market prices are used as assessment norms for social welfare maximization to reflect "value" of goods and service and efficiency of resource allocation. These defects are feasible to analyze the market operation mechanism, but they will send out danger signals when applied by government in making reasonable policy decisions. The theoretical framework of value-neutral is the works of classic and neoclassical economics, which has guided the practice of many countries for policy making during last century. Economists attribute to "economic man" an omniscient rationality as if theirs were a "science of choice" both for personal and social [31]. However, in parallel to neoclassical economics, the interdisciplinary field of ecological economics has developed, and it tends to consider the economy as co-evolving, rather than simply growing [11]. The concept of "uneconomic growth" has been put forward to describe the notion that economic growth has cost more than it worth [5].

Fisheries are renewable resources that are supported by integrated social, economic and natural ecosystem. To pursue the profitability of fisheries, fisheries resources have been overexploited and economic rent dissipation in most 
coastal areas. Hence, fisheries ideally should be chosen as a typical case to illustrate the concept of uneconomic growth. The uneconomic cost of fishing activities in the Pearl River Estuary have been defined from quantifiable and non-quantifiable factors: The quantifiable costs of fishing, which are relatively easy to identify and quantify the total costs of losing physical assets. The physical assets can be living (fishery resource, fishermen) either non-living (vessels, fuel, fishing gear and equipment). The non-quantifiable costs of fishing, which is difficult to identify and be evaluated by money. The cost of intangible assets in fishing community, which is associated with both social and cultural values are manifested by the loss of opportunities, rights and interests, etc.

According to the report of China Economic Weekly [40], in the Southern China Sea (Figure 1), marine capture fisheries circulated a "226 rule", that is, only $20 \%$ of fishing boats are able to make profit, another $20 \%$ are able to preserve their capital, and up to $60 \%$ of fishing boats make losses. The industry insider said: with the expanding of fishing effort, the total catch per unit effort (CPUE) are decreasing, but oil prices are rising, hence the revenue from fishing can't keep up with the rising costs. Mostly the entire fishing sectors are losing money and are relying solely on government's diesel subsidies to survive. Although fishers lost money, they could continue to maintain production via the diesel subsidies, otherwise almost none would have been able to sustain operations. Fisheries management in China realized that to maintain supplies of protein to China's high population, subsidies for loss-making fishing boats were essential. Thus, it can be observed that fishery subsides not only drive overexploiting but also aggravate destructiveness of other fishing activities, such as bottom trawling would not be profitable without substantial fuel subsidies and repeatedly associated with illegal, unreported, and unregulated fishing, which are the major causes of lost benefit and hampered achievement of sustainable fisheries.

While it is possible to estimate the costs of unreasonable subsidy decisions, which resulting in long-term inefficiencies in marine fisheries, there are other costs that are more difficult to quantify, which need to be considered. One of the most important is the unjust fuel subsidy policy that has led to a loss of human capital for small-scale fisheries. The small-scale fisheries have less financially support than larger-scale fisheries, as the diesel fuel subsidies according to the vessels' power are lower. Previous studies have shown small-scale fisheries operate at lower cost than large-scale fisheries, which with less disruption to ecosystem and higher employment rates [20]. Many young people leave their villages for big cities in search of higher salaries and better work conditions.

The theory of uneconomic growth is very helpful for evaluating the relevant government fishery policies based on the criterion of "welfare maximization" criteria. In addition, this theory could be used in the formulation of fisheries management policies, which consider both the objective constraints of ecosystems capacity as well as the legitimate needs of all fishermen. To prevent more 
degradation from exploiting ecosystems and to improve societal benefits, restructuring fishing fleets is urgently needed. Understanding the trade-offs between the socio-economic system and ecosystem could help government and stakeholders to have an informed discussion about fishery policy making from all fishing communities.

\subsection{Cost of Fisheries Subsidy Policy}

The classify of fishery subsidies has been a controversial issue [36]. Here, according to the effects of fishery subsidies on the sustainable exploitation of fish stocks which is categorized in Sumaila [41], that is, a) beneficial subsidies, b) harmful subsidies and c) ambiguous subsidies.

Beneficial subsidies refer to fisheries management policies that optimize the social investment in natural capital, which promote the recovery of fishery resources through ecosystem restoration measures, such as fisheries research and marine protected areas establishment, to achieve biological and economic optimum [36]. Harmful subsidies refer to various forms of subsidies lead to overfishing and overcapacity [41]. Fuel subsidy has been widely regarded as a bad subsidy and is fundamental contributor to fishing overcapacity, whose negative ecological and socio-economic impacts constantly concealed by government support [42]. Subsidies that reduce the cost and increase revenue for fishery can insulate fishermen from economic signals, countering the economic incentive to stop fishing when it is unprofitable. Ambiguous subsidies refer to policies that do not yet know whether their effects are beneficial or harmful, such as fishing boat buyback program, fishermen assistance program, and fishing community development program.

Fisheries subsidies of Guangdong province reached 520.935 million dollars in 2014, which accounts for $68 \%$ of local marine capture GDP (Figure 5). The reason behind these huge costs are policies based on short-term thinking, and a lack of understanding of the value of small-scale, low-energy fisheries in the overall configuration of fisheries after restructuring. As the survey suggest that largescale fisheries can survived with higher diesel subsidies than small-scale fisheries, making it more likely to perform better economically. This demonstrates that success of social economy is not only reflected in whether the profit maximization is realized, but also reflected in whether income redistribution is fair and reasonable.

The implementation of a series of policies to encourage the improvement of the welfare of small-scale fisheries will prevent the deterioration of the fishing community. If the entire fishery community continues to deteriorate, it will loss of a specific valuable fishing culture and possibly lead to the depletion of new fish stocks. But it is not too late to change direction, and China's Ministry of Agriculture has announced that fisheries diesel subsidies would be cancelled from 2016. The national and provincial fisheries investment funds need to initiate a readjustment of fisheries in accordance with new development goals. In the future, the PRD fisheries should be reshaped as an important part of sus- 
tainable socio-economic development in the Pearl River Delta region.

\section{Conclusions}

The purpose of this study is to assessing the actual cost of fishing activities and fishery policy implementation from economic, ecological, and social aspects. The ecosystem of the PRD has been severely depleted due to overfishing and is considered to be in undesirable state of socio-economic and ecological targets.

Based on the concept of "uneconomic growth" in ecological economics, the costs of economic growth exceed the benefits of its growth due to the constrains imposed by the capacity of the marine ecosystem. This study applied the concept of "unjust uneconomic growth" to show that uneconomic growth is the underlying cause of many social problems and disruptions because the benefits and costs of economic growth are distributed unjustly. This concept has been applied to the analysis of fishing activities and fishery policies in the Pearl River Estuary as fishery resource collapsed from the 1990s, which is a typical example of uneconomic growth in which benefits and costs were distributed unfairly. This paper reveals three categories of costs that were detrimental to the coastal fisheries, some of which were quantifiable, but many were difficult to quantify, and therefore, more research is needed to evaluate all the costs.

\section{Acknowledgements}

This study was conducted under the following projects: Zhejiang Provincial Social Science Planning Fund Program (Key Research Institute of Philosophy and Social Sciences for Ecological Civilization, Grant No. 16JDGH089); Zhejiang Provincial Natural Science Foundation of China (Grant No. LY18G030035); "An ecological computable general equilibrium (ECGE) model for marine fishery management: Linking ecosystem and socio-economic system", supported by $\mathrm{Na}$ tional Natural Science Foundation of China (Contract No. 71303220); Foundation of Applied Economics Base for Humanities and Social Science in Zhejiang Province (Grant No. 2016YJYB07).

\section{References}

[1] Nunan, F. (2014) Wealth and Welfare? Can Fisheries Management Succeed in Achieving Multiple Objectives? A Case Study of Lake Victoria, East Africa. Fish \& Fisheries, 15, 134-150. https://doi.org/10.1111/faf.12012

[2] Pomeroy, R., et al. (2016) Improving Marine Fisheries Management in Southeast Asia: Results of a Regional Fisheries Stakeholder Analysis. Marine Policy, 65, 20-29. https://doi.org/10.1016/j.marpol.2015.12.002

[3] White, C., et al. (2008) Marine Reserve Effects on Fishery Profit. Ecology Letters, 11, 370. https://doi.org/10.1111/j.1461-0248.2007.01151.x

[4] Cao, L., et al. (2017) Opportunity for Marine Fisheries Reform in China. PNAS, 114, 435-442. https://doi.org/10.1073/pnas.1616583114

[5] Daly, H.E., et al. (2011) Ecological Economics: Principles and Applications. Island Press, Washington DC. 
[6] Sabau, G. and Jong, M.V.Z.D. (2014) From Unjust Uneconomic Growth to Sustainable Fisheries in Newfoundland: The True Costs of Closing the Inshore Fishery for Groundfish. Marine Policy, 61, 376-389.

https://doi.org/10.1016/j.marpol.2014.11.012

[7] Failler, P. and Pan, H. (2007) Global Value, Full Value and Societal Costs: Capturing the True Cost of Destroying Marine Ecosystems. Social Science Information, 46, 109-134. https://doi.org/10.1177/0539018407073660

[8] Kallis, G., Kerschner, C. and Martinez-Alier, J. (2012) The Economics of Degrowth. Ecological Economics, 84, 172-180. https://doi.org/10.1016/j.ecolecon.2012.08.017

[9] Alier, J.M. (2009) Socially Sustainable Economic De-Growth. Development \& Change, 40, 1099-1119. https://doi.org/10.1111/j.1467-7660.2009.01618.x

[10] Weiss, M. and Cattaneo, C. (2017) Degrowth-Taking Stock and Reviewing an Emerging Academic Paradigm. Ecological Economics, 137, 220-230. https://doi.org/10.1016/j.ecolecon.2017.01.014

[11] van den Bergh, J. and Kallis, G. (2012) Growth, A-Growth or Degrowth to Stay within Planetary Boundaries? Journal of Economic Issues, 46, 909-920. https://doi.org/10.2753/JEI0021-3624460404

[12] Drews, S. and Antal, M. (2016) Degrowth: A "Missile Word" That Backfires? Ecological Economics, 126, 182-187. https://doi.org/10.1016/j.ecolecon.2016.04.001

[13] van den Bergh, J. (2011) Environment versus Growth-A Criticism of "Degrowth" and a Plea for “A-Growth". Ecological Economics, 70, 881-890. https://doi.org/10.1016/j.ecolecon.2010.09.035

[14] Clary, B.J. (2011) The Spirit Level: Why Greater Equality Makes Society Stronger. Review of Social Economy, 69, 239-243. https://doi.org/10.1080/00346764.2010.512523

[15] Kalimeris, P., Richardson, C. and Bithas, K. (2014) A Meta-Analysis Investigation of the Direction of the Energy-GDP Causal Relationship: Implications for the Growth-Degrowth Dialogue. Journal of Cleaner Production, 67, 1-13. https://doi.org/10.1016/j.jclepro.2013.12.040

[16] Exner, A., Lauk, C. and Zittel, W. (2015) Sold Futures? The Global Availability of Metals and Economic Growth at the Peripheries: Distribution and Regulation in a Degrowth Perspective. Antipode, 47, 342-359. https://doi.org/10.1111/anti.12107

[17] Béné, C. (2003) When Fishery Rhymes with Poverty: A First Step beyond the Old Paradigm on Poverty in Small-Scale Fisheries. World Development, 31, 949-975. https://doi.org/10.1016/S0305-750X(03)00045-7

[18] Béné, C., et al. (2011) Testing Resilience Thinking in a Poverty Context: Experience from the Niger River Basin. Global Environmental Change, 21, 1173-1184. https://doi.org/10.1016/j.gloenvcha.2011.07.002

[19] Béné, C. and Friend, R.M. (2011) Poverty in Small-Scale Fisheries. Progress in Development Studies, 11, 119-144. https://doi.org/10.1177/146499341001100203

[20] Pomeroy, R.S. (2012) Managing Overcapacity in Small-Scale Fisheries in Southeast Asia. Marine Policy, 36, 520-527. https://doi.org/10.1016/j.marpol.2011.10.002

[21] Duan, L.J., et al. (2009) A Trophic Model of the Pearl River Delta Coastal Ecosystem. Ocean \& Coastal Management, 52, 359-367. https://doi.org/10.1016/j.ocecoaman.2009.04.005

[22] Li, Y.Z., Chen, G.B. and Sun, D.R. (2000) Analysis of the Composition of Fishes in the Pearl River Estuarine Waters. Journal of Fisheries of China, 24, 312-317.

[23] Mai, X.J., et al. (2007) The Fisheries of the South China Sea. Guangdong Economy 
Press, Guangzhou, 290.

[24] Wang, Y., Hu, J.F., Pan, H.R., Li, S.Y. and Failler, P. (2016) An Integrated Model for Marine Fishery Management in the Pearl River Estuary: Linking Socio-Economic Systems and Ecosystems. Marine Policy, 64, 135-147. https://doi.org/10.1016/j.marpol.2015.11.014

[25] Jia, X.P., Li, C.H. and Qiu, Y.S. (2005) Survey and Evaluation of Guangdong Marine Fishery Resources and the Measures for Sustainable Utilization. Chinese Ocean Press, Beijing.

[26] Shen, G. and Heino, M. (2014) An Overview of Marine Fisheries Management in China. Marine Policy, 44, 265-272. https://doi.org/10.1016/j.marpol.2013.09.012

[27] Zhong, Y. and Power, G. (1997) Fisheries in China: Progress, Problems, and Prospects. Canadian Journal of Fisheries \& Aquatic Sciences, 54, 224-238. https://doi.org/10.1139/f96-265

[28] Wang, Y., Li, S.Y., Duan, L.J. and Liu, Y. (2012) Fishery Policy Exploration in the Pearl River Estuary Based on an Ecosim Model. Ecological Modeling, 230, 34-43. https://doi.org/10.1016/j.ecolmodel.2012.01.017

[29] Wang, Y., Duan, L.J., Li, S.Y., Zeng, Z.Y. and Failler, P. (2015) Modeling the Effect of the Seasonal Fishing Moratorium on the Pearl River Estuary Using Ecosystem Simulation. Ecological Modelling, 312, 406-416. https://doi.org/10.1016/j.ecolmodel.2015.06.011

[30] Pauly, D., Christensen, V., Dalsgaard, J., Froese, R. and Torres Jr., F. (1998) Fishing down Food Webs. Science, 279, 860-863. https://doi.org/10.1126/science.279.5352.860

[31] Mankiw, N.G. (2011) Principles of Economics. 5th Edition, South-Western Cengage Learning, Mason, $\mathrm{OH}$.

[32] Keynes, J.M. (2010) The General Theory of Employment, Interest, and Money. Economic Record, 12, 28-36.

[33] Teh, L.S.L., Teh, L.C.L. and Sumaila, U.R. (2011) Quantifying the Overlooked Socio-Economic Contribution of Small-Scale Fisheries in Sabah, Malaysia. Fisheries Research, 110, 450-458. https://doi.org/10.1016/j.fishres.2011.06.001

[34] Yang, B.H. and Zhou, J.W. (2013) The Effect Valuation of 2012 Summer Fishing Moratorium in the South China Sea-Base on the Comparison among Trawl, Purse Seine and Gill Net Fishery. Chinese Fisheries, 3, 73-75.

[35] Sumaila, U.R., et al. (2010) A Bottom-Up Re-Estimation of Global Fisheries Subsidies. Jounal of Bioeconomics, 12, 201-225. https://doi.org/10.1007/s10818-010-9091-8

[36] Mallory, T.G. (2016) Fisheries Subsidies in China: Quantitative and Qualitative Assessment of Policy Coherence and Effectiveness. Marine Policy, 68, 74-82. https://doi.org/10.1016/j.marpol.2016.01.028

[37] Li, X., Liang, H.Y., Zhang, W.K., Wang, M.D. and Sun, H.F. (2015) The Analysis of the Influences of Fisheries Diesel Allowance Policy on Guangdong Ocean Fishing Industry. Journal of Guangdong Ocean University, 35, 38-44.

[38] Yu, H. and Yu, Y. (2008) Fishing Capacity Management in China: Theoretic and Practical Perspectives. Marine Policy, 32, 351-359. https://doi.org/10.1016/j.marpol.2007.07.004

[39] Béné, C., et al. (2016) Contribution of Fisheries and Aquaculture to Food Security and Poverty Reduction: Assessing the Current Evidence. World Development, 79, 177-196. https://doi.org/10.1016/j.worlddev.2015.11.007 
[40] Guo, F. (2012) Chinese Fishermen Who Were Forced to Shore. China Economic Weekly, People's Daily, Beijing.

[41] Sumaila, U.R., et al. (2016) Global Fisheries Subsidies: An Updated Estimate. Marine Policy, 69, 189-193. https://doi.org/10.1016/j.marpol.2015.12.026

[42] Carvalho, N., et al. (2011) Estimating the Impacts of Eliminating Fisheries Subsidies on the Small Island Economy of the Azores. Ecological Economics, 70, 1822-1830. https://doi.org/10.1016/j.ecolecon.2011.05.013 